\title{
EFFECT OF FOLIAR APPLICATION OF UREA AND PLANOFIX ON THE FOLIAGE YIELD OF CORIANDER
}

\author{
Abdur Rakib1*, M. Moniruzzaman'2, M. Hasan ${ }^{3}$ and M.M. Rahman' ${ }^{3}$ \\ Received 30 April 2015, Revised 29 May 2015, Accepted 26 June 2015, Published online 30 June 2015
}

\begin{abstract}
An experiment on coriander (Coriandrum sativum L.) was conducted at the experimental field of Department of Horticulture, Bangabandhu Sheikh Mujibur Rahman Agricultural University (BSMRAU), Gazipur during November 2012 to April 2013 to find out the suitable foliar doses and application frequency of urea and planofix (NAA). The experiment was laid out in factorial randomized complete block design with three replications. The treatment consisted of six foliar doses viz. $\mathrm{T}_{1}$ (Tap water as control), $\mathrm{T}_{2}\left(0.10 \%\right.$ urea), $\mathrm{T}_{3}(0.25 \%$ urea), $\mathrm{T}_{4}\left(0.40 \%\right.$ urea), $\mathrm{T}_{5}\left(5 \mathrm{ppm}\right.$ planofix) and $\mathrm{T}_{6}(10 \mathrm{ppm}$ planofix) and three application frequencies viz. $F_{1}$ [20 days after sowing (20 DAS)], $F_{2}$ (30 DAS) and $F_{3}(20$ and 30 DAS). Maximum foliage yield (6.94 t/ ha) was recorded in $10 \mathrm{ppm}$ planofix coupled with it's twice application at 20 and 30 DAS which was closely followed the foliage yield ( $6.33 \mathrm{t} /$ ha) by 5 ppm planofix with the same application frequency. The foliage yield was increased with the increase in urea concentration. The highest foliage yield ( $5.37 \mathrm{t} / \mathrm{ha}$ ) was also recorded from twice application of urea and planofix at 20 and 30 DAS, respectively. Planofix 10 ppm with its twice application at 20 and 30 DAS gave the highest benefit-cost of ration 2.51.
\end{abstract}

Keywords: Coriander, Urea, Planofix, Foliage Yield

\footnotetext{
${ }^{1}$ Horticulture Division, Bangladesh Institute of Nuclear Agriculture (BINA), BAU Campus, Mymensingh-2202

${ }^{2}$ Horticulture Research Centre, Bangladesh Agriculture Research Institute (BARI), Gazipur-1701, Bangladesh

${ }^{3}$ Department of Horticulture, Bangabandhu Sheikh Mujibur Rahman Agricultural University, Salna, Gazipur-1706

*Corresponding author's email: rakibag8_pstu@yahoo.com (Abdur Rakib)
}

Note: The authorship is changed on 23.02.2016 from Abdur Rakib ${ }^{1}$, M. Kamruzzaman ${ }^{*}$, Soyema Khatun ${ }^{1}$ and M. Moniruzzaman ${ }^{2}$ to Abdur Rakibi*, M. Moniruzzaman², M. Hasan ${ }^{3}$ and M.M. Rahman ${ }^{3}$. The authorship is changed due to request of the principal author to add two co-authors of his major professor and advisory committee member of postgraduate study and two co-authors are excluded from the authorship and acknowledged them for their contribution in the manuscript.

\section{Introduction}

Coriander (Coriandrum sativum L.) is an important spice crop known as 'Dhania' in Bangla. It is native to Southern Europe and the Mediterranean region and is extensively grown throughout the world. It has been cultivated since human antiquity (Tiwari and Agrawal, 2004). Preciously Italy is presumed as the native place of coriander (Thumburaj and Singh, 2004). Coriander grows under a wide range of conditions in temperate regions but normally cultivated in winter in Bangladesh (Ahmed and Haque, 1985). Practically all parts of the plant are used as spice, which have pleasant aromatic odor. Coriander leaves and seeds are valued as food mainly for its high carotene content. Its leaves are one of the rich sources of vitamin C (250 mg/ $100 \mathrm{~g})$ and vitamin A $(10,460$ I.U./ 100g). Its seeds also contain considerable amount of vitamin C (12 $\mathrm{mg} / 100$ ) and vitamin A (175 I.U. / 100 g) (Pruthi, 1998). The fresh leaves are an ingredient in many foods such as chutneys and salads. The dried fruits also have a fragrant odor and pleasant aromatic taste. The dried ground fruits are the major ingredients of the curry powder. The odor and taste are due to the essential oil content, which varies from 0.1 to 1.0 percent in the dry seeds (Kumar et al., 1994). It has medicinal purpose too. Chemicals derived from coriander leaves were found to have antibacterial activity against Salmonella choleraesuis, and this activity was found to be caused in part by these chemicals acting as nonionic surfactants. Coriander has been documented as a traditional treatment for type 2 diabetes. A study on mice found coriander extract had both insulin-releasing and insulinlike activity (http:// en. wikipedia. org/ wiki/ Coriander). For successful production, all necessary nutrients must be supplied to the plants judiciously in a sufficient amount. Among different major plant nutrients, nitrogen is required in large amounts (Brady, 1990) and this macronutrient makes the plant leaves succulent and soft. It is a short duration crop and is generally harvested within 30 to 50 days after sowing (Babik, 1999). The efficiency of nitrogenous fertilizer depends to a great extent, on the time and method of application, because nitrogenous fertilizers which are highly water soluble and easily lost from soil in various ways. The nitrogen loss may be averted over by using different application methods mainly through foliar application. Planofix is a substance containing naphthalene acetic acid (NAA). It increases cell elongation, there by increases the leaf area of the plants and ultimately increases the foliage yield of coriander. Information is scanty on the use of urea and planofix as foliar application for coriander foliage production in Bangladesh. Keeping the above facts in view the present experiment has been undertaken to 
determine the suitable foliar doses of urea and planofix for higher coriander foliage yield, to find out the suitable application frequency of urea and planofix for higher coriander foliage yield and to determine the profitable foliar doses and application frequency of urea and planofix for coriander cultivation.

\section{Materials and Methods}

The experiment was conducted at the Horticulture Research Farm of Bangabandhu Sheikh Mujibur Rahman Agricultural University, Gazipur during the period from November 2012 to April 2013 to study the effect of urea and planofix on coriander foliage yield. The field experiment having two factors was laid out in Randomized Complete Block Design (RCBD) with three replications. The treatment consisted of six foliar doses viz. $\mathrm{T}_{1}$ (Tap water as control), $\mathrm{T}_{2}(0.10$ $\%$ urea), $\mathrm{T}_{3}\left(0.25 \%\right.$ urea), $\mathrm{T}_{4}\left(0.40 \%\right.$ urea), $\mathrm{T}_{5}$ (5 ppm planofix) and $\mathrm{T}_{6}(10 \mathrm{ppm}$ planofix) and three application frequencies viz. $\mathrm{F}_{1}$ [20 days after sowing (20 DAS) $], F_{2}(30 \mathrm{DAS})$ and $\mathrm{F}_{3}(20$ and 30 DAS). Replication to replication and plot to plot distance were $1.0 \mathrm{~m}$ and $0.5 \mathrm{~m}$, respectively. The size of each unit plot was $3 \mathrm{~m} \times 1 \mathrm{~m}\left(3 \mathrm{~m}^{2}\right)$. The total area of the experiment was $332 \mathrm{~m}^{2}$. Total number of plots was 54. The planofix is a product of Bayer Crop Science containing NAA use as foliar spray. The variety Rosina of Pahuja seed company, India was used as plant material. The seeds (fruits) were rubbed for separating two mericarps (seeds) and were soaked in water for 24 hours to enhance germination. Seed were also treated with Bavistin @ $2 \mathrm{~g}$ per $\mathrm{kg}$ of seeds before sowing. The seeds were sown in rows $10 \mathrm{~cm}$ apart continuously by hand @ $40 \mathrm{~kg} / \mathrm{ha}$ (Moniruzzaman, 2011). To allow uniform sowing in rows seeds were mixed with some loose soil and watering after sowing just to supply sufficient moisture needed for quick germination. The field was kept weed free initially by hand weeding.

Table 1. Interaction effect of foliar spray and application frequency of urea and planofix on plant spread, plant height, leaf length, leaves / plant, plant weight, green plants/ $\mathrm{m}^{2}$ and plant weight $/ \mathrm{m}^{2}$ of coriander at 40 days after sowing

\begin{tabular}{|c|c|c|c|c|c|c|c|}
\hline $\begin{array}{c}\text { Treatment } \\
\text { combination }\end{array}$ & $\begin{array}{l}\text { Plant } \\
\text { spread }\end{array}$ & $\begin{array}{l}\text { Plant } \\
\text { height }\end{array}$ & Leaf length & Leaves/plant & $\begin{array}{c}\text { Plant } \\
\text { weight }(\mathrm{g})\end{array}$ & $\begin{array}{c}\text { Green } \\
\text { plants } / \mathrm{m}^{2}\end{array}$ & $\begin{array}{l}\text { Plant weight } \\
/ \mathrm{m}^{2}(\mathrm{Kg})\end{array}$ \\
\hline $\mathrm{T}_{1} \mathrm{~F}_{1}$ & $17.82 \mathrm{~g}$ & $13.11 \mathrm{i}$ & $11.52 \mathrm{~g}$ & $8.77 \mathrm{gh}$ & $1.43 j$ & 433.3 & $0.62 \mathrm{j}$ \\
\hline $\mathrm{T}_{1} \mathrm{~F}_{2}$ & $17.74 \mathrm{~g}$ & $12.99 \mathrm{i}$ & $12.21 \mathrm{efg}$ & $8.57 \mathrm{~h}$ & $1.65 j$ & 433.7 & $0.71 \mathrm{ij}$ \\
\hline $\mathrm{T}_{1} \mathrm{~F}_{3}$ & $18.20 \mathrm{~g}$ & $12.99 \mathrm{i}$ & $12.65 \mathrm{~d}-\mathrm{g}$ & $8.97 \mathrm{efg}$ & $2.27 \mathrm{hi}$ & 436.0 & $0.81 \mathrm{hi}$ \\
\hline $\mathrm{T}_{2} \mathrm{~F}_{1}$ & $19.12 \mathrm{fg}$ & $14.08 \mathrm{~h}$ & $12.30 \mathrm{efg}$ & $8.83 \mathrm{fgh}$ & $2.31 \mathrm{ghi}$ & 435.0 & $0.84 \mathrm{hi}$ \\
\hline $\mathrm{T}_{2} \mathrm{~F}_{2}$ & $18.88 \mathrm{~g}$ & $13.97 \mathrm{~h}$ & $11.86 \mathrm{fg}$ & $8.97 \mathrm{efg}$ & $2.08 \mathrm{i}$ & 434.7 & $0.76 \mathrm{hi}$ \\
\hline $\mathrm{T}_{2} \mathrm{~F}_{3}$ & 20.65ef & $14.34 \mathrm{gh}$ & $13.13 \mathrm{c}-\mathrm{f}$ & $9.27 \mathrm{~b}-\mathrm{e}$ & $2.55 \mathrm{efg}$ & 434.3 & $0.88 \mathrm{gh}$ \\
\hline $\mathrm{T}_{3} \mathrm{~F}_{1}$ & $20.66 \mathrm{ef}$ & $14.75 \mathrm{ef}$ & $12.13 \mathrm{fg}$ & $9.23 \mathrm{cde}$ & $2.32 \mathrm{ghi}$ & 435.7 & $0.85 \mathrm{hi}$ \\
\hline $\mathrm{T}_{3} \mathrm{~F}_{2}$ & 20.77def & $14.63 \mathrm{fg}$ & $12.82 \mathrm{~d}-\mathrm{g}$ & $9.20 \mathrm{c}-\mathrm{f}$ & $2.46 \mathrm{fgh}$ & 436.0 & $0.99 \mathrm{fg}$ \\
\hline $\mathrm{T}_{3} \mathrm{~F}_{3}$ & 21.28de & $15.04 \mathrm{de}$ & $13.95 \mathrm{a}-\mathrm{d}$ & $9.10 \mathrm{~d}-\mathrm{g}$ & $3.28 \mathrm{~cd}$ & 431.3 & $1.05 \mathrm{ef}$ \\
\hline $\mathrm{T}_{4} \mathrm{~F}_{1}$ & $22.20 \mathrm{~b}-\mathrm{e}$ & $15.35 \mathrm{od}$ & $13.95 \mathrm{a}-\mathrm{d}$ & $9.30 \mathrm{~b}-\mathrm{e}$ & $2.69 \mathrm{ef}$ & 434.0 & $1.08 \mathrm{ef}$ \\
\hline $\mathrm{T}_{4} \mathrm{~F}_{2}$ & 21.45 cde & $15.33 \mathrm{~cd}$ & $14.05 \mathrm{a}-\mathrm{d}$ & $9.57 \mathrm{bc}$ & $3.18 \mathrm{~d}$ & 432.3 & 1.09 ef \\
\hline $\mathrm{T}_{4} \mathrm{~F}_{3}$ & 23.25abc & $16.13 \mathrm{ab}$ & $14.90 \mathrm{ab}$ & $9.57 \mathrm{bc}$ & $3.69 \mathrm{~b}$ & 433.7 & $1.13 \mathrm{def}$ \\
\hline $\mathrm{T}_{5} \mathrm{~F}_{1}$ & $21.60 \mathrm{cde}$ & $15.14 \mathrm{de}$ & $13.30 \mathrm{c}-\mathrm{f}$ & $9.30 \mathrm{~b}-\mathrm{e}$ & $2.79 \mathrm{e}$ & 434.0 & $1.16 \mathrm{def}$ \\
\hline $\mathrm{T}_{5} \mathrm{~F}_{2}$ & $21.48 \mathrm{cde}$ & $15.16 \mathrm{de}$ & $13.28 \mathrm{c}-\mathrm{f}$ & $9.10 \mathrm{~d}-\mathrm{g}$ & $3.48 \mathrm{bc}$ & 433.7 & 1.16 ode \\
\hline $\mathrm{T}_{5} \mathrm{~F}_{3}$ & $22.41 \mathrm{be}$ & $15.74 \mathrm{bc}$ & $14.67 \mathrm{abc}$ & $9.63 \mathrm{~b}$ & $3.95 \mathrm{a}$ & 432.3 & $1.29 \mathrm{abc}$ \\
\hline $\mathrm{T}_{6} \mathrm{~F}_{1}$ & 22.51bod & $15.74 \mathrm{bc}$ & $13.73 \mathrm{~b}-\mathrm{e}$ & $9.30 \mathrm{~b}-\mathrm{e}$ & $3.63 \mathrm{~b}$ & 436.0 & $1.26 \mathrm{bcd}$ \\
\hline $\mathrm{T}_{6} \mathrm{~F}_{2}$ & $23.59 \mathrm{ab}$ & $15.85 \mathrm{~b}$ & $14.18 \mathrm{a}-\mathrm{d}$ & $9.47 \mathrm{bcd}$ & $3.67 \mathrm{~b}$ & 435.0 & $1.34 \mathrm{ab}$ \\
\hline $\mathrm{T}_{6} \mathrm{~F}_{3}$ & $23.62 \mathrm{a}$ & $16.48 \mathrm{a}$ & $15.34 \mathrm{a}$ & $10.20 \mathrm{a}$ & $4.05 \mathrm{a}$ & 435.3 & $1.42 \mathrm{a}$ \\
\hline $\begin{array}{l}\text { Level of } \\
\text { sionificanc }\end{array}$ & $*$ & $*$ & * & $*$ & & NS & 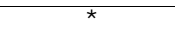 \\
\hline CV (\%) & 4.56 & 1.61 & 6.22 & 2.16 & 3.98 & 5.64 & 7.61 \\
\hline
\end{tabular}

Means having different letters are not significantly different at $5 \%$ level of probability by DMRT
Weeding was done after 25 days after sowing (DAS). Data were recorded on the plant spread, plant height, longest leaf length, leaves per plant, plant weight, green plants $/ \mathrm{m}^{2}$, green plant weight $/ \mathrm{m}^{2}$, foliage yield ( $\mathrm{t} / \mathrm{ha}$ ). All the data were compiled and analyzed statistically by MSTAT--C program. The mean comparison was done at $5 \%$ level of probability following the Duncan's Multiple Range Test (DMRT).

\section{Results and Discussion}

\section{Foliar spray and application frequency of urea and planofix on plant growth}

There was a significant interaction of foliar and application frequency of urea and planofix on plant spread, plant height, longest leaf length, leaves/plant, and plant weight, number of plants $/ \mathrm{m}^{2}$ and plant weight $/ \mathrm{m}^{2}$ at 40 DAS (Table 1). The maximum plant spread $(23.62 \mathrm{~cm})$ was observed in combination of $\mathrm{T}_{6} \mathrm{~F}_{3}$ which was closely followed by $\mathrm{T}_{6} \mathrm{~F}_{2}(23.59 \mathrm{~cm})$ and $\mathrm{T}_{4} \mathrm{~F}_{3}$ $(23.25 \mathrm{~cm})$ and minimum was found in $\mathrm{T}_{1} \mathrm{~F}_{2}$ $(17.74 \mathrm{~cm})$ which was statistically similar to $\mathrm{T}_{1} \mathrm{~F}_{1}$ $(17.84 \mathrm{~cm}), \mathrm{T}_{1} \mathrm{~F}_{3}(18.20 \mathrm{~cm}), \mathrm{T}_{2} \mathrm{~F}_{1}(19.12 \mathrm{~cm})$ and $\mathrm{T}_{2} \mathrm{~F}_{2}(18.88 \mathrm{~cm})$ (Table 1). The highest plant height was observed in $\mathrm{T}_{6} \mathrm{~F}_{3}(16.48 \mathrm{~cm})$ which was at par with $\mathrm{T}_{4} \mathrm{~F}_{3}(16.13 \mathrm{~cm})$ and the lowest plant height was found in $\mathrm{T}_{1} \mathrm{~F}_{3}$ and $\mathrm{T}_{1} \mathrm{~F}_{2}(12.99 \mathrm{~cm})$ which were statistically similar to $\mathrm{T}_{1} \mathrm{~F}_{1}(13.11 \mathrm{~cm})$ (Table 1). The result of plant height influenced by $\mathrm{T}_{4}(0.40 \%$ urea) is in agreement with the report of Sharangi et al. (2012). This observation also supported by the observation of Shanu et al. (2013). The maximum leaf length was recorded in $\mathrm{T}_{6} \mathrm{~F}_{3}(15.34 \mathrm{~cm})$ which was statistically similar to $\mathrm{T}_{4} \mathrm{~F}_{3}(14.90 \mathrm{~cm}), \mathrm{T}_{5} \mathrm{~F}_{3}(14.67 \mathrm{~cm}), \mathrm{T}_{6} \mathrm{~F}_{2}(14.18 \mathrm{~cm})$, $\mathrm{T}_{4} \mathrm{~F}_{2}(14.05 \mathrm{~cm})$ and $\mathrm{T}_{4} \mathrm{~F}_{1}(13.95 \mathrm{~cm})$ where the lowest leaf length $(11.52 \mathrm{~cm})$ was found in $\mathrm{T}_{1} \mathrm{~F}_{1}$ (Table 1). 
This result is in partial agreement with Vedamuthu et al. (1996) who got higher values of growth parameter with 40 ppm NAA and partially supported by the observation of Shanu et al. (2013) who reported leaf length was increased with the increase of application frequency. The maximum leaves per plant were found in $\mathrm{T}_{6} \mathrm{~F}_{3}$ (10.20) which were followed by $\mathrm{T}_{5} \mathrm{~F}_{3}(9.63)$ (Table 1). The minimum leaf number was recorded in $\mathrm{T}_{1} \mathrm{~F}_{2}$ (8.57). The result corroborate with the report of Piyush and Sen (2002) who reported that NAA $50 \mathrm{ppm}$ gave the highest number of green leaves of coriander per plant (22.03/ plant) in multicast system. The maximum plant weight was found in $\mathrm{T}_{6} \mathrm{~F}_{3}(4.05 \mathrm{~g})$ which was statistically similar to $\mathrm{T}_{5} \mathrm{~F}_{3}(3.95 \mathrm{~g})$ but minimum weight was recorded in $\mathrm{T}_{1} \mathrm{~F}_{1}(1.43 \mathrm{~g})$ which was at par withT $\mathrm{F}_{2}(1.65 \mathrm{~g})$ (Table 1). The green plants per square meter were found insignificant for foliar spray and application frequency of urea and planofix and their interaction. Interaction of foliar spray and application frequency had significant effect on green plant yield/ $\mathrm{m}^{2}$. The maximum foliage weight was recorded in $\mathrm{T}_{6} \mathrm{~F}_{3}$ $\left(1.42 \mathrm{~kg} / \mathrm{m}^{2}\right)$ which was statistically similar to $\mathrm{T}_{6} \mathrm{~F}_{2}\left(1.34 \mathrm{~kg} / \mathrm{m}^{2}\right)$ and $\mathrm{T}_{5} \mathrm{~F}_{3}\left(1.29 \mathrm{~kg} / \mathrm{m}^{2}\right)$ and the lowest $\left(0.62 \mathrm{~kg} / \mathrm{m}^{2}\right)$ was observed in $\mathrm{T}_{1} \mathrm{~F}_{1}$ which was statistically similar to $\mathrm{T}_{1} \mathrm{~F}_{2}\left(0.71 \mathrm{~kg} / \mathrm{m}^{2}\right)$ (Table 1).

\section{Foliage yield ( $t / h a)$}

The foliage yield was significantly influenced by different foliar spray of urea and planofix. The maximum foliage yield was recorded in $T_{6}(6.53$ $\mathrm{t} / \mathrm{ha}$ ) which was significantly higher than the other treatments and followed by $T_{5}(5.87 \mathrm{t} / \mathrm{ha})$ $\mathrm{T}_{4}(5.40 \mathrm{t} / \mathrm{ha}), \mathrm{T}_{3}(4.74 \mathrm{t} / \mathrm{ha})$ and $\mathrm{T}_{2}(4.05 \mathrm{t} / \mathrm{ha})$ and the minimum yield from control $\mathrm{T}_{1}$ (3.50 t/ha) (Fig. 1). Planofix $10 \mathrm{ppm}\left(\mathrm{T}_{6}\right)$ gave the highest foliage yield of coriander because all the growth parameters viz. plant spread, plant height, leaves/plant, plant weight and green plant yield per square meter were maximum at that treatment. This is in consonance with the result of Badgujar and Warhal (1999). Foliage yield had also strong positive correlation with all growth parameters. Among the nitrogen doses $0.40 \%$ urea ( $\mathrm{T}_{4}$ treatment) gave the maximum yield ( 540 t/ha) compared to other nitrogen doses. This correlations the result of Badgujar et al. (1977) who reported that foliar application of $0.25 \%$ urea 20 days after sowing gave the maximum foliage leaf yield of $8.38 \mathrm{t} /$ ha in coriander while control treatment gave only $3.38 \mathrm{t} / \mathrm{ha}$. It might be nitrogen is an integral component of many compounds, including chlorophyll and enzymes, essential for plant growth processes. It is an essential component of amino acids and related proteins, which are critical not only building block for plant tissue but also in the cell nuclei and protoplasm. Nitrogen is essential for carbohydrate use within plants and stimulates root growth and development as well as the uptake of other nutrients. This element encourages above ground vegetative parts and gives a deep green color to the leaves (Brady, 1990).

The foliage yield was significantly influenced by different application frequencies. The maximum foliage yield was recorded in $F_{3}(5.37 \mathrm{t} / \mathrm{ha})$ followed by $\mathrm{F}_{2}(4.97 \mathrm{t} / \mathrm{ha})$ and minimum foliage yield was observed in $F_{1}(4.71 \mathrm{t} / \mathrm{ha}$ ) (Fig. 2). The urea and planofix spray twice at 20 and 30 DAS $\left(F_{3}\right)$ gave maximum values in respect of all growth parameters viz plant spread, plant height, leaves/plant, plant weight and green plant weight per square meter. This observation partially supported by the observation of Shanu et al. (2013) who reported vegetative yield was increased with the increase of application frequency of foliar spray.

Interaction effect of foliar spray and application frequency had significant effect on foliage yield. The maximum foliage yield was recorded in $\mathrm{T}_{6} \mathrm{~F}_{3}$ (6.95 ton/ha) which was statistically similar to $\mathrm{T}_{5} \mathrm{~F}_{3}$ (6.33 ton/ha) and the lowest foliage yield was obtained from $\mathrm{T}_{1} \mathrm{~F}_{1}$ (3.04 ton/ha) which was statistically similar to $\mathrm{T}_{1} \mathrm{~F}_{2}(3.51 \mathrm{t} / \mathrm{ha})$ (Fig. 3). It is evident that planofix $10 \mathrm{ppm}$ or $5 \mathrm{ppm}$ when interacted with twice application of planofix at 20 and 30 DAS gave the maximum foliage yield. The solution of urea $0.40 \%$ when interacted with its twice application at 20 and $30 \mathrm{DAS}\left(\mathrm{F}_{3}\right)$ produced reasonable yield of foliage (5.54 t/ha) that was higher than control other interaction of urea and $\mathrm{F}_{3}$. 


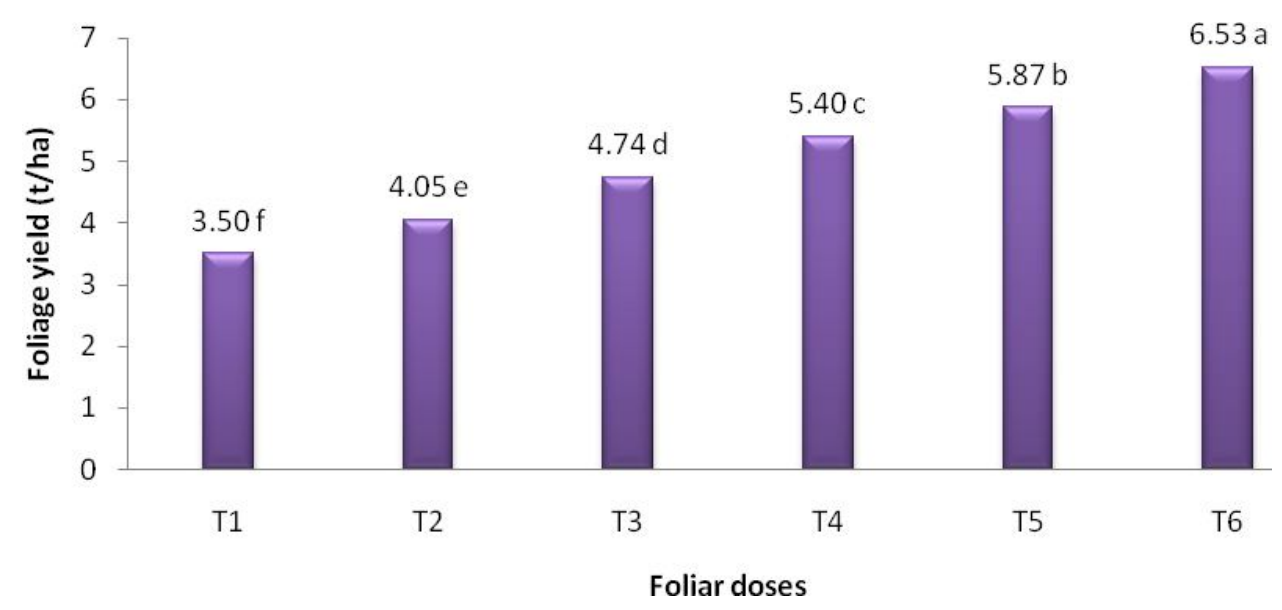

Fig. 1. Foliage yield influenced by foliar spray of urea and planofix of coriander. Figures placed on top of the bar with different letters are significantly different at $5 \%$ level of probability by DMRT.

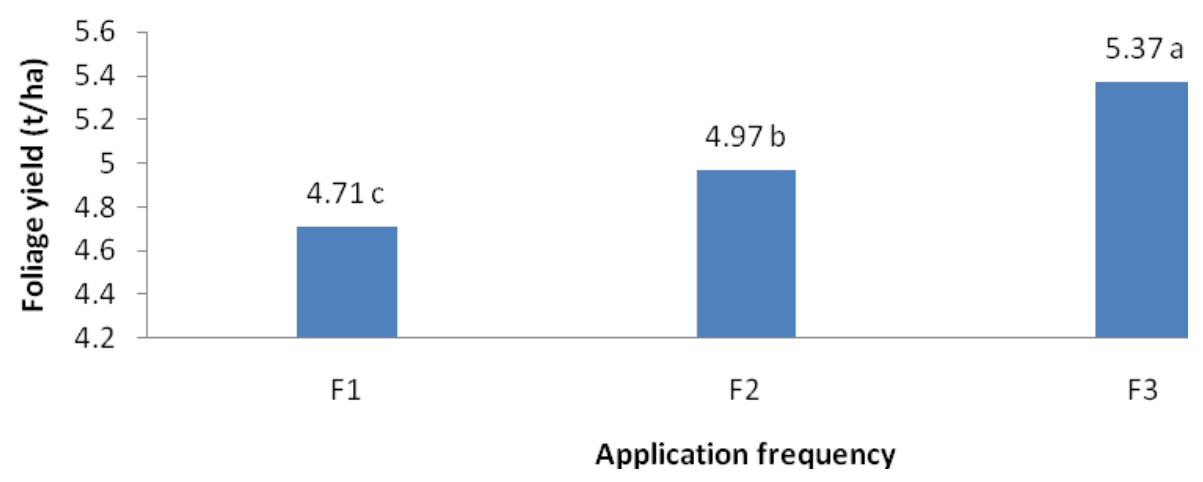

Fig. 2. Foliage yield influenced by application frequency of urea and planofix of coriander. Figures placed on top of the bar with different letters are significantly different at $5 \%$ level of probability by DMRT

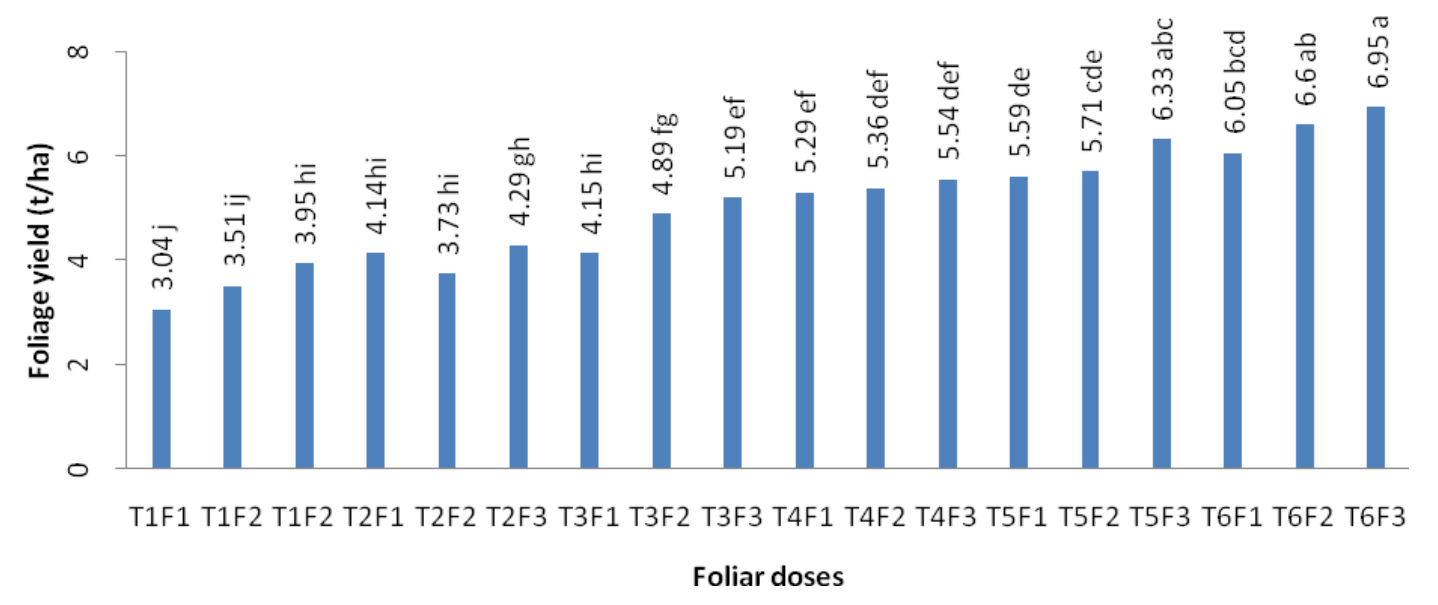

Fig. 3. Foliage yield influenced by interaction of foliar spray and application frequency of urea and planofix of coriander. Figures placed on top of the bar with different letters are significantly different at $5 \%$ level of probability by DMRT. 


\section{Conclusion}

The growth parameters viz. plant spread, plant height, leaf length, leaves/plant, plant weight, plant weight $/ \mathrm{m}^{2}$ and foliage yield were found maximum from the foliage spray of $10 \mathrm{ppm}$ planofix as well as it twice application at 20 and 30 days after sowing. Planofix $5 \mathrm{ppm}$ in combination with it's twice spray at 20 and 30 DAS produced the second highest foliage yield of coriander. The solution of urea $0.40 \%$ coupled with twice spray at 20 and 30 DAS produced reasonable foliage yield of coriander. Thus, 10 ppm planofix with its twice application may be used for maximum production of foliage yield of coriander.

\section{Acknowledgement}

The authors are very much grateful to $\mathrm{M}$. Kamruzzaman and Soyema Khatun, Scientific Officers, Bangladesh Institute of Nuclear Agriculture for their contribution in data analysis and manuscript preparation.

\section{References}

Ahmed, N.U. and Haque, M.M. 1985. Effect of dates of sowing on the growth and seed yield of coriander varieties. Bangladesh J. Agric. 10(2): 23-27.

Babik, I. 1999. Sowing and harvest time on plant growth, yield and sprout quality of Coriander (Coriandrum sativum L.). Research Institute of Vegetable Crop (RIVC), Skierniewice, Poland. p. 11.

Badgujar, C.D. and Warhal, K.N. 1999. Effect of seed soaking and wrapping on growth and yield of vegetable coriander. J. Maharashtra Agric. Uni. 13(3): 344-345.

Badgujar, C.D., Lawande, K.E., Kale, P.N., and Choudhuri, K.G. 1997. Response of coriander to foliar application of urea. Current Res. Rep. 3(2): 118-119.

Brady, N.C. 1990. The Nature and Properties of Soils. $10^{\text {th }}$ ed. Macmillan publishing Co. New York. $315 \mathrm{p}$. http:// en. wikipedia. org/ wiki/ Coriander. Retrieved on, 17/ 04/ 2014.

Kumar, N., Khader, M.A., Rangaswami, P. and Irulappan, I. 1994. Introduction to spices, plantation crops, medicinal and aromatic plants. Oxford and IBH Pub. Co. Pvt. Ltd., New Delhi. 305p.

Moniruzzaman, M. 2011. Foliage and seed production technology of coriander. $\mathrm{PhD}$. Dissertation. Department of Horticulture. Bangabandhu Sheikh Mujibur Rahman Agricultural University, Salna, Gazipur. 264 $\mathrm{p}$.

Piyush, V. and Sen, N.L. 2002. The Impact of plant growth regulators on growth and biochemical constituents of Coriander (Coriandrum sativum L.). Indian J. Hort. 14 (1): 3-4.

Pruthi, J.S. 1998. Spices and condiments. $5^{\text {th }}$ ed. National Book Trust. New Delhi, India. 109 p.

Shanu, I.S., Naruka, P.P., Singh, R.P., Shaktawat, S. and Verma, K.S. 2013. Effect of foliar spray of thiourea on growth, yield and quality of coriander (Coriandrum sativum L.). Int. J . Seed Spices 3(1): 20-25.

Sharangi, B., Chatterjee, R., Nanda, M.K. and Kumar, R. 2012. Grouth and leaf yield dynamics of cool season coriander as influenced by cutting and foliar nitrogen application. The Bioscan 7(3): 544-631.

Thumburaj, S. and Singh, N. 2004. Vegetables, Tubercrops and Spices. Kuldeep Sharma, incharge Directorate and information and Publication of Agriculture. Indian Council of Agril Res . Krishi Anusandhan Bhaban, Pusa, New Delhi 110012. pp. 371-374.

Tiwari, R.S. and Agrawal, A. 2004. Production Technology of Spices. India. pp. 254-271.

Vedamuthu, P.G.B., Khader, F. and Rajan, S. 1996. Effect of different plant growth regulators and split application of nitrogen on the productivity of coriander. South Indian Hort. 37(5): 287. 